\title{
KONTRIBUSI MOTIVASI BELAJAR DAN KOMPETENSI PEDAGOGIK GURU TERHADAP PRESTASI BELAJAR SOSIOLOGI
}

\author{
Ambros Leonangung Edu \\ STKIP Santu Paulus Ruteng, Flores-NTT \\ edutie 81088@yahoo.co.id \\ Petrus Redy Partus Jaya \\ STKIP Santu Paulus Ruteng, Flores-NTT \\ petrusredypartusjaya@gmail.com
}

\begin{abstract}
Abstrak
Penelitian ini bertujuan mendeskripsikan kontribusi motivasi belajar siswa dan kompetensi pedagogik guru terhadap prestasi belajar Sosiologi. Jenis penelitian yang digunakan adalah penelitian korelasi eksplanatoris dengan pendekatan kuantitatif. Populasi penelitian berjumlah 2428 siswa yang berasal dari SMA N 1, SMA N 2, dan MAN di Kecamatan Langke Rembong propinsi NTT. Jumlah sampel ditentukan berdasarkan teknik proporsional dan simple random sampling. Proses pengumpulan data dilakukan dengan menggunakan teknik angket dan teknik tes. Teknik angket digunakan untuk mengumpulkan informasi terkait tinggi rendahnya motivasi siswa dan kompetensi pedagogik guru. Teknik tes berupa tes pilihan ganda digunakan untuk mengukur prestasi belajar Sosiologi siswa. Data yang terkumpul dianalisis menggunakan teknik analisis korelasi sederhana dan korelasi ganda. Hasil analisis korelasi sederhana menunjukan terdapat hubungan positif antara motivasi belajar ( $\left.\mathrm{X}_{1}\right)$ siswa dengan prestasi belajar Sosiologi $(\mathrm{Y})$ dan terdapat korelasi positif antara kompetensi pedagogik guru terhadap prestasi belajar Sosiologi siswa. Koefisien korelasi motivasi belajar dengan prestasi belajar adalah $r_{y .1}=0,643$. Koefisien korelasi kompetensi pedagogik guru $\left(\mathrm{X}_{2}\right)$ terhadap prestasi belajar Sosiologi adalah $r_{y .2}=0,666$. Taraf signifikansi kedua korelasi tersebut lebih kecil dari 0,05 yang membuktikan hipotesis adanya korelasi positif antara variabel motivasi dan kompetensi pedagogik terhadap prestasi belajar Sosiologi siswa. Koefisien korelasi antara $\left(\mathrm{X}_{1}\right)$ dan $\left(\mathrm{X}_{2}\right)$ terhadap $\mathrm{Y}$ meningkat ketika dihitung secara bersama-sama menggunakan teknik korelasi ganda. Besaran koefisien korelasi kedua variabel tersebut terhadap prestasi belajar Sosiologi adalah sebesar $r_{y .12}=$ 0,754 . Dengan kata lain, kontribusi bersama variabel motivasi belajar dan kompetensi pedagogik terhadap prestasi belajar Sosiologi adalah sebesar 57,2\%. Sebesar $42.8 \%$ hasil belajar Sosiologi dijelaskan oleh faktor lain yang tidak diteliti.
\end{abstract}

Kata Kunci: motivasi, kompetensi, prestasi 


\section{PENDAHULUAN}

Tujuan sentral dari setiap proses dan reformasi pendidikan di Indonesia adalah mencapai lulusan siswa yang berprestasi. Prestasi berhubungan dengan kualitas dan produktivitas dari hasil (output) usaha siswa dari suatu aktivitas (Kirkpatrik \& Lewis, 1995:8). Maka, prestasi belajar berarti kualitas dan produktivitas dari hasil yang dicapai oleh siswa setelah ia melakukan perubahan belajar. UNESCO (2000: 53) menyebut prestasi belajar merupakan kinerja akademik (academic performance) karena berkaitan dengan produktivitas siswa dalam bidang akademik. Femi Olivia (2011: 73) menyebut prestasi belajar sebagai "puncak hasil belajar" yang mencerminkan hasil kesuksesan belajar siswa terhadap tujuan belajar yang telah ditetapkan. Hasil belajar dapat meliputi aspek kognitif, afektif, dan psikomotorik.

Dalam proses pencapaian prestasi belajar, usaha keras dan perjuangan tanpa kenal lelah mutlak diperlukan. Keinginan yang kuat dan usaha yang maksimal menggerakkan aktivitas secara lebih efektif. Secara lebih rinci, Sudiki (2004 : 12) mengatakan bahwa sesungguhnya orang belajar 10\% dari apa yang dibaca, 20\% dari apa yang didengar, 30\% dari apa yang dilihat, 50\% dari apa yang dilihat dan didengar, $70 \%$ dari apa yang dikatakan, dan 90\% dari apa yang dikatakan dan dilakukan. Siswa yang berprestasi adalah siswa yang rajin membaca, mendengar, melihat, memahami, dan melakukan kegiatan belajar. Prestasi belajar dapat diketahui melalui tes.

Bagaimanapun, dalam kehidupan praksis, banyak sekolah di tanah air ini tidak mempunyai tujuan yang jelas dan tidak mampu mengelola sumber daya yang tersedia untuk meningkatkan prestasi akademik para siswa (Yulaelawati, 2009: 176-177). Fenomena keterpurukan tersebut hendak menunjukkan adanya sindrom akut yang menyandera proses dan reformasi pendidikan di Indonesia. Meskipun negara ini memiliki jumlah siswa terbesar di dunia (The World Bank, 2004: 15), yaitu lebih dari 46 juta siswa serta 2,7 juta guru di lebih dari 250.000 sekolah, yang memungkinkan sistem pendidikannya menjadi ketiga terbesar di Asia dan keempat di dunia setelah China, India, dan Amerika Serikat (The World Bank, 2010-2011: 2), semua itu tampak sekadar prestasi kuantitas dan bukan prestasi kualitas. Padahal, inti dari kemajuan pendidikan adalah prestasi kualitas pendidikan yang handal.

Fenomena serupa dialami siswasiswa sekolah menengah atas di Kecamatan Langke Rembong, Kabupaten Manggarai, Provinsi Nusa Tenggara 
Timur. Langke Rembong adalah kecamatan yang ada di jantung ibukota Kabupaten Manggarai. Dengan demikian, berbicara tentang prestasi para siswa SMA dan MA Negeri di Kecamatan Langke Rembong berarti berbicara tentang sekolah-sekolah yang berada di Ruteng, ibukota pemerintahan kabupaten setempat. Langke Rembong merupakan kawasan favorit, karena selain sebagai pusat pemerintahan, ia juga menjadi pusat aktivitas sosial, politik, ekonomi, dan pendidikan. Ironisnya, kualitas pendidikan di kawasan favorit itu kurang memuaskan.

Menguaknya persoalan prestasi belajar para siswa di wilayah tersebut diduga dipengaruhi banyak faktor, antara lain motivasi belajar siswa dan kompetensi pedagogik guru yang rendah. Motivasi adalah dorongan utama, gerakan psikologis, sebuah "driving force", yang memungkinkan siswa untuk melakukan tindakan belajar yang serius, konsisten, dan terfokus pada tujuan berprestasi. Motivasi belajar itu sendiri bersifat intrinsik dan ekstrinsik. Motivasi intrinsik berarti bahwa siswa memiliki dorongan yang kuat untuk berprestasi, rasa ingin tahu yang tinggi, kedisplinan, dan mampu mengatasi kesulitan belajar. Kenyataannya, aktivitas belajar yang didorong karena motivasi intrinsik lebih sukses daripada yang didorong oleh motivasi ekstrinsik (Suryabrata, 1995 : 70). Pendapat ini diperkuat oleh bukti-bukti mutakhir yang menunjukkan bahwa baik motivasi ekstrinsik maupun motivasi intrinsik sama-sama penting untuk belajar. Siswa termotivasi untuk belajar saat dia diberi pilihan, senang menghadapi kesulitan yang sesuai dengan kemampuannya, dan mendapat imbalanyang mengandung nilai transformasional tetapi bukan dipakai untuk melakukan kontrol (Santrock, 2008: 514).

Hal yang sama dikatakan Sardiman (2011: 93-95) bahwa agar siswa belajar dengan baik, siswa perlu dimotivasi dengan memberi skor terhadap tugas, memberi hadiah, menciptakan kompetisi, menumbuhkan kesadaran belajar, memberi ulangan, mengecek hasil belajar, pujian, hukuman, mendorong hasrat dan minat belajar, serta merumuskan tujuan belajar yang diakui siswa. Bentuk-bentuk motivasi seperti itu penting untuk mencapai prestasi. Dengan prestasi, siswa mendapat pengakuan dan penerimaan dari sahabat, guru, dan orangtua. Keberhasilan di sekolah menjadi cara terbaik agar siswa dapat diterima dan diakui. Dalam hal ini, siswa berusaha belajar dan mencapai prestasi untuk mengesankan orang lain sebagai simbol keberhasilan. 
Dengan demikian, fungsi motivasi bagi siswa adalah: Pertama, menjadi daya penggerak bagi siswa untuk melepaskan energi belajarnya mencapai tujuan prestasi dalam hal ini. Kedua, mendorong siswa untuk selalu konsisten atau disiplin dalam mencapai tujuan belajar. Ketiga, mempersiapkan siswa mampu mengatasi kesulitan dalam proses belajar. Keempat, menjadi penggerak bagi siswa untuk memiliki rasa ingin tahu yang tinggi terkait aspek-aspek yang dipelajari. Jika belajar mensyaratkan adanya motivasi, maka tidak ada siswa yang akan belajar dengan baik tanpa adanya motivasi. Siswa yang mencapai tujuan belajar tentu saja adalah siswa yang memiliki motivasi dan telah termotivasi dalam belajar.

Di samping oleh lemahnya motivasi belajar siswa, prestasi belajar juga pengaruhi oleh rendahnya kompetensi pedagogik guru. Sebagai pendidik, guru memang harus kompeten (PP/19/2005, Psl. 28). Ia adalah ahli pedagogik. Ahli pedagogik berarti pandai dalam membimbing anak untuk berprestasi (Sadulloh, 2010: 2). Singkatnya, guru harus memiliki kompetensi pedagogik yang menyata dalam pengetahuan yang luas, keterampilan teknis-praktis, dan sikap profesional. Kompetensi pedagogik adalah kemampuan didaktik-metodik guru dalam seluruh rangkaian kegiatan pembelajaran di sekolah mulai dari persiapan dan desain pembelajaran, penyampaian materi pelajaran, variasi pengajaran, penguasaan media dan teknologi pembelajaran, dan interaksi dengan siswa.

Kompetensi pedagogik guru menentukan prestasi belajar siswa. Heyneman dan Loxley, melalui riset mereka pada tahun 1983 di 29 negara, menemukan bahwa kualitas pendidikan yang ditunjukkan oleh prestasi belajar siswa, sepertiganya ditentukan oleh guru. Menurut riset itu, pada 16 negara sedang berkembang dari 29 negara yang diteliti itu, kontribusi guru terhadap prestasi belajar sebesar 34\%, manajemen $22 \%$, waktu belajar $18 \%$, dan sarana fisik $26 \%$; sementara pada 13 negara industri, kontribusi guru sebesar 36\%, manajemen $23 \%$, waktu belajar $22 \%$, dan sarana fisik 19\%. Nana Sudjana dari risetnya menunjukkan adanya korelasi positif antara kemampuan mengajar $(0,78)$, penguasaan metodologi pengajaran $(0,90)$, dan penguasaan materi $(0,79)$ terhadap prestasi belajar siswa (Tim Pengembang FIP-UPI: 2007, 72).

Dengan melihat bahwa motivasi belajar dan kompetensi pedagogik penting terhadap prestasi belajar siswa, maka peneliti tertarik untuk membahas lebih lanjut dalam bentuk penelitian korelasi eksplanatoris tentang kontribusi motivasi belajar dan kompetensi 
pedagogik guru terhadap prestasi belajar Sosiologi siswa SMU dan MA Negeri di Kecamatan Langke Rembong, Nusa Tenggara Timur. Penentuan mata

\section{METODE PENELITIAN}

Penelitian ini tergolong dalam jenis penelitian korelasi eksplanatoris dengan pendekatan kuantitatif. Penentuan jenis penelitian didasarkan pada tujuan dan rumusan masalah. Penelitian ini bertujuan untuk mendeskripsikan korelasi antara variabel motivasi belajar siswa $\left(X_{1}\right)$ dan kompetensi pedagogik guru $\left(\mathrm{X}_{2}\right)$ terhadap prestasi belajar Sosiologi siswa (Y). Selain itu, penelitian ini juga bertujuan menghitung kontribusi variabel motivasi dan kompetensi pedagogik guru baik kontribusi unik maupun kontribusi pelajaran Sosiologi didasarkan pada rendahnya nilai rata-rata hasil Ujian Nasional mata pelajaran tersebut dibandingkan mata pelajaran lainnya.

bersama terhadap prestasi belajar Sosiologi siswa. Pendekatan kuantitatif dipilih sebab peneliti tidak bertujuan menggali data yang mendalam terkait motivasi atau kompetensi pedagogik. Peneliti sekadar mencari pembuktian statistik yang dapat menjelaskan adanya hubungan dan kontribusi variabel motivasi siswa dan kompetensi pedagogik guru terhadap prestasi belajar Sosiologi siswa. Desain penelitian yang digunakan dalam penelitian ini ditunjukan melalui gambar berikut.

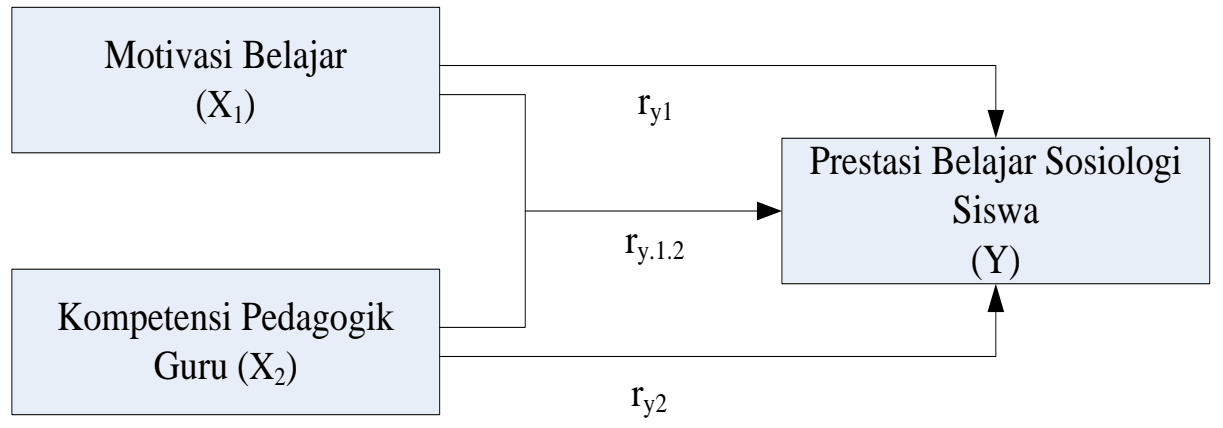

Gambar 1.

Desain Penelitian

Populasi dalam penelitian ini orang. Yang menjadi populasi adalah seluruh siswa SMA Negeri 1, terjangkau adalah seluruh siswa kelas SMA Negeri 2 dan MA di kecamatan XII dari ketiga sekolah tersebut Langke Rembong yang berjumlah 2428 dengan jumlah 698 orang. Kelas XII 
dipilih sebagai populasi karena terjangkau. Maka, dari 698 orang siswa merupakan kelas tahun terakhir yang kelas XII pada ketiga sekolah, telah mempelajari Sosiologi sejak kelas diperoleh sampel sebanyak 70 orang. XI sedangkan kelas-kelas lain tidak Pengambilan sampel ditentukan dipilih karena selama penelitian, berdasarkan teknik gabungan antara mereka belum mempelajari materi proporsional dan simple random sampling. Sosiologi. Merujuk pada Arikunto (1999:107), peneliti menetapkan 10\% Penetapan sampel tersebut dapat dilihat pada Tabel 1 di bawah ini: jumlah sampel dari populasi

Tabel 1.

Penetapan Jumlah Sampel Penelitian

\begin{tabular}{clcccc}
\hline No & Nama Sekolah & $\begin{array}{c}\text { Jumlah } \\
\text { Seluruh } \\
\text { Siswa }\end{array}$ & $\begin{array}{c}\text { Jumlah Siswa } \\
\text { Kelas XII }\end{array}$ & $\begin{array}{c}\text { Proporsi } \\
\text { Sampel }\end{array}$ & Sampel \\
\hline 1 & SMU Negeri 1 & 1336 & 420 & $420: 698 \times 70$ & 42 \\
2 & SMU Negeri 2 & 941 & 221 & $221: 698 \times 70$ & 22 \\
3 & MAN & 151 & 57 & $57: 698 \times 70$ & 6 \\
& Jumlah & $\mathbf{2 4 2 8}$ & $\mathbf{6 9 8}$ & $\mathbf{1 0} \%$ & $\mathbf{7 0}$ \\
\hline
\end{tabular}

Sumber: MAN, SMAN 1, SMAN 2 Kecamatan Langke Rembong, Dinas PPO

Kabupaten Manggarai

Dalam penelitian ini, peneliti akan kesulitan, dan rasa ingin tahu. Angket mengumpulkan data terkait motivasi, pengukuran kompetensi pedagogik guru kompetensi pedagogik dan prestasi dikembangkan berdasarkan indicator belajar Sosiologi. Data motivasi siswa dan kemampuan membuat persiapan dan kompetensi pedagogik guru desain pembelajaran, kemampuan dikumpulkan melalui teknik angket. menyampaikan materi pelajaran, Peneliti menyusun masing-masing 25 kemampuan membuat variasi pengajaran, butir pernyataan yang dapat digunakan kemampuan menguasai media dan untuk mendapatkan informasi terkait teknologi pembelajaran, dan kemampuan motivasi siswa dan kompetensi berinteraksi dengan siswa. Sementara itu, pedagogik guru. Angket pengukuran untuk mengetahui prestasi belajar siswa, motivasi belajar siswa dikembangkan peneliti menggunakan teknik tes berupa berdasarkan 4 indikator motivasi, yaitu tes pilihan ganda dengan 40 butir dorongan untuk berprestasi, kedisiplinan pertanyaan. Data-data yang telah dalam belajar, kesiapan mengatasi dikumpulkan peneliti dianalisis 
menggunakan teknik korelasi sederhana dan korelasi ganda. Teknik analisis korelasi sederhana digunakan untuk menghitung koefisien korelasi tiap variabel indepen terhadap variabel prestasi belajar Sosiologi. Teknik korelasi ganda digunakan untuk mengukur

\section{HASIL PENELITIAN}

Penelitian ini dilakukan terhadap 70 orang responden. Dari 70 orang responden tersebut diperoleh data terkait motivasi belajar, persepsi siswa tentang kompetensi pedagogik guru, dan hasil belajar sosiologi. Berdasarkan teori, ketiga variabel ini memiliki korelasi yang kuat. Motivasi dan kompetensi pedagogik guru memiliki korelasi yang kuat terhadap hasil belajar siswa. Semakin tinggi kadar motivasi dan kompetensi pedagogik guru maka hasil belajar siswa semakin tinggi. tingkat korelasi motivasi belajar dan kompetensi pedagogik secara bersama terhadap prestasi belajar Sosiologi siswa. Penggunaan teknik korelasi ini menuntut pemenuhan prasyarat normalitas data dan multikolinearitas.

Untuk membuktikan asumsi teoritis ini, berikut disajikan data deskriptif serta pembuktian hipotesis korelasional terkait variabel motivasi, kompetensi pedagogik, dan hasil belajar siswa.

Berdasarkan respon yang diperoleh dari 70 orang siswa terhadap angket dan soal tes yang diberikan, diperoleh data motivasi belajar, kompetensi pedagogik, dan hasil belajar Sosiologi siswa sebagaimana disajikan dalam Tabel 2 berikut.

Tabel 2.

Deskripsi Data Variabel Penelitian

\begin{tabular}{|l|c|c|c|}
\hline & Mean & \multicolumn{1}{|c|}{$\begin{array}{c}\text { Std. } \\
\text { Deviation }\end{array}$} & N \\
\hline HASIL_BELAJAR & 33.2571 & 3.63831 & 70 \\
\hline MOTIVASI & 40.2571 & 6.98588 & 70 \\
\hline K_PEDAGOGIK & 82.0714 & 13.20883 & 70 \\
\hline
\end{tabular}

Pada Tabel 2 di atas tampak bahwa rerata hasil belajar Sosiologi siswa sebesar 33,257. Jika dibandingkan dengan jumlah soal tes yang diujikan kepada siswa, besaran rerata tersebut tergolong dalam kategori baik atau dengan kata lain, siswa berhasil menjawab benar sebagian besar $(80 \%)$ soal tes yang diberikan. Dalam penelitian ini tingginya rerata hasil belajar Sosiologi siswa dapat dijelaskan berdasarkan motivasi dan persepsi atau penilaian siswa terhadap kompetensi 
pedagogik guru. Tabel 2 di atas juga menunjukan bahwa rerata motivasi belajar siswa sebesar 40,257. Besaran rerata motivasi siswa tergolong dalam kategori rendah jika dibandingkan dengan butir pernyataan dan skala yang terdapat dalam angket pengukuran motivasi. Dalam angket pengukuran motivasi siswa terdapat 25 butir pernyataan dengan 5 skala pada setiap butir pernyataan (5=Selalu; 4=Sering; 3=Kadang-Kadang; 2=Jarang; 1=Tidak Pernah). Rendahnya rerata motivasi belajar siswa menunjukan bahwa banyak siswa yang tidak memiliki tendency to achive success $(T-S)$ atau kecenderungan untuk berprestasi. Kondisi ini secara matematis dapat ditulis T S < T F. Kecenderungan untuk menjadi gagal lebih tinggi dibandingkan kecenderungan untuk sukses atau berprestasi. Dalam melakukan aktivitas belajar, para siswa cenderung tidak memiliki orientasi yang jelas. Bagi siswa, belajar sebatas rutinitas paksaan yang membosankan. Tantangan-tantangan yang diberikan guru melalui tugas dikerjakan hanya untuk memenuhi tuntutan guru. Tidak ada nilai intrinsic yang tertanam atau berusaha ditumbuhkan siswa.

Hal yang berbeda terjadi pada hasil pengukuran persepsi siswa terhadap kompetensi pedagogik guru. Sebagian besar siswa memiliki persepsi yang baik terhadap kompetensi pedagogik guru. Terbukti bahwa besaran rerata persepsi siswa terhadap kompetensi pedagogik guru adalah 82,071. Rerata ini berada pada kategori baik jika dibandingkan dengan jumlah butir pernyataan dan skala yang digunakan dalam angket pengukuran persepsi siswa terhadap kompetensi pedagogik guru. Terdapat 25 butir pernyataan dan 5 skala dalam angket pengukuran persepsi siswa terhadap kompetensi pedagogik guru. Para siswa memberikan persepsi yang positif terhadap keterampilan guru dalam membuat persiapan dan desain pembelajaran, menyampaikan pelajaran, membuat variasi pengajaran, menguasai media dan teknologi pembelajaran, dan interaksi guru dengan siswa.

Dalam Tabel 2 ditunjukan bahwa rerata hasil belajar Sosiologi siswa sebesar 33,25 dari 40 butir soal tes. Tingginya hasil belajar siswa ini dipastikan tidak disebabkan oleh kualitas tes yang rendah. Proporsi tingkat kesukaran soal tes adalah Sukar $=2 \%$; Sedang $=72 \%$; dan Mudah $=$ $0,8 \%$. Sebagian besar soal tes memiliki tingkat kesukaran Sedang. Dengan proporsi seperti ini, soal tes dapat dipakai. Bila merujuk pada nilai deskriptis motivasi belajar dan kompetensi pedagogik guru, rerata hasil belajar ini disebabkan oleh kompetensi pedagogik guru yang baik. 
Data deskriptif yang ditunjukan memiliki sebaran data yang normal dalam Tabel 2 menimbulkan pertanyaan dengan nilai signifikansi lebih kecil dari terkait korelasi antar variabel. Apakah terdapat korelasi positif variabel motivasi belajar siswa terhadap hasil belajar siswa? Apakah kompetensi pedagogik guru memiliki hubungan dengan hasil belajar siswa? Apakah motivasi belajar dan kompetensi pedagogik guru secara bersama-sama berkontribusi terhadap hasil belajar siswa?

Untuk membuktikan ada tidaknya hubungan dan menghitung besaran koefisien determinan dari variabel motivasi belajar, kompetensi pedagogik guru, dan kontribusi bersama kedua variabel tersebut terhadap hasil belajar, peneliti menggunakan teknik analisis korelasi parsial. Dipastikan bahwa prasyarat pengujian seperti normalitas data dan multikolinearitas antar variabel independen terpenuhi. Hasil pengujian normalitas data menggunakan teknik Kolmogorov Smirnov membuktikan bahwa ketiga variabel yang diteliti 0,05 . Pengujian multikolinearitas antar variabel independen juga telah memenuhi syarat, yaitu tidak terjadi multikolinearitas antar variabel motivasi dan variabel kompetensi pedagogik guru. Berdasarkan perhitungan collinearity statistics nilai tolerance berada di atas 0,1 $(0,751>0,1)$ dan VIF (Varian Inflation Factor) berada di bawah $10 \quad(1,351<10)$. Tidak adanya multikolinearitas antar variabel independen memastikan bahwa kontribusi bersama variabel motivasi dan kompetensi pedagogik guru terhadap hasil belajar siswa tidak didominasi oleh satu variabel independen. Pemenuhan prasyarat pengujian ini menjadi dasar untuk melakukan penguijan hipotesis statistic terkait korelasi antar variabel motivasi, kompetensi pedagogik, dan hasil belajar Sosiologi siswa.

Hasil analisis korelasi antar variabel dapat dilihat pada gambar berikut.

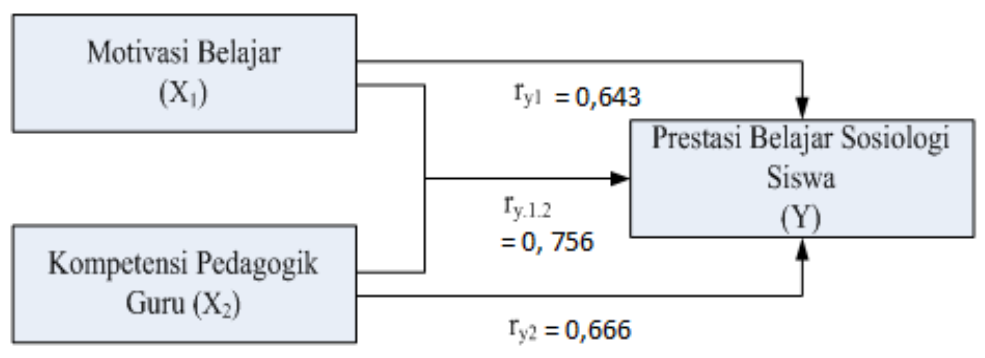

Gambar 2.

Besaran Koefisien Korelasi variabel Motivasi Belajar, Kompetensi Pedagogik Guru dan Hasil Belajar Sosiologi Siswa 
Pada Gambar 2 tampak bahwa koefisien korelasi variabel motivasi belajar $\left(\mathrm{X}_{1}\right)$ terhadap Prestasi Belajar Sosiologi Siswa (Y) adalah $r_{y 1}=0,643$; koefisien korelasi variabel kompetensi pedagogik guru $\left(\mathrm{X}_{2}\right)$ terhadap Prestasi Belajar Sosiologi Siswa (Y) adalah $r_{y 2}=$ 0,666; dan koefisien korelasi variabel motivasi belajar $\left(X_{1}\right)$ dan kompetensi pedagogik guru $\left(\mathrm{X}_{2}\right)$ secara bersamasama terhadap Prestasi Belajar Sosiologi
Siswa (Y) adalah $r_{y \cdot 12}=0,756$. Hasil perhitungan koefisien korelasi ini berada dalam rentangan 0,60 - 0,799 yang berarti korelasi antar variabel independen (motivasi dan kompetensi pedagogik guru) terhadap variabel dependen (hasil belajar Sosiologi) tergolong kuat dan signifikan. Nilai signifikansi korelasi variabel motivasi, kompetensi pedagogik terhadap hasil belajar lebih kecil dari 0,05.

Tabel 3.

\begin{tabular}{|l|l|r|r|r|}
\hline \multicolumn{5}{|c|}{ Koefisien Korelasi $r_{y 1}$ dan $r_{y 2}$} \\
\hline \multirow{3}{*}{$\begin{array}{l}\text { Pearson } \\
\text { Correlation }\end{array}$} & HASIL_BELAJAR & MOTIVASI & K_PEDAGOGIK \\
\cline { 2 - 5 } & HASIL_BELAJAR & 1.000 & .643 & .666 \\
\cline { 2 - 5 } & MOTIVASI & .643 & 1.000 & .499 \\
\cline { 2 - 5 } Sig. (1-tailed) & K_PEDAGOGIK & .666 & .499 & 1.000 \\
\cline { 2 - 6 } & HASIL_BELAJAR & .000 \\
\cline { 2 - 6 } & MOTIVASI & .000 & .000 & .000 \\
\cline { 2 - 5 } & K_PEDAGOGIK & .000 & .000 \\
\hline
\end{tabular}

Nilai signifikansi korelasi yang Sosiologi adalah 44,35\% $\left(\left(r_{y 2}\right)^{2} \times 100 \%\right)$. lebih kecil dari 0,05 membuktikan Fakta ini menunjukan bahwa variabel hipotesis yang menyatakan bahwa motivasi belajar siswa dan kompetensi terdapat hubungan positif antara variabel pedagogik guru secara mandiri hanya motivasi belajar dengan Hasil Belajar dapat menjelaskan sekitar $40 \%$ factor Sosiologi dan terdapat hubungan positif yang berpengaruh terhadap Hasil Belajar antara variabel kompetensi pedagogik Sosiologi. Sekitar lebih dari 50\% belum guru dengan Hasil Belajar Sosiologi siswa. dapat dijelaskan. Hasil berbeda diperoleh Sementara itu, besarnya koefisien ketika kontribusi variabel motivasi dan determinan variabel motivasi terhadap Hasil Belajar adalah 41,34\% $\quad\left(\left(r_{y 1}\right)^{2} \mathrm{x}\right.$ kompetensi pedagogik guru terhadap $100 \%$ dan variabel kompetensi Hasil Belajar Sosiologi dihitung bersamapedagogik guru terhadap Hasil Belajar berikut. 
Tabel 4.

\begin{tabular}{|c|c|c|c|c|c|c|c|c|c|}
\hline \multicolumn{10}{|c|}{ Koefisien Korelasi $r_{y .12}$} \\
\hline \multirow[b]{2}{*}{ Model } & \multirow[b]{2}{*}{$\mathrm{R}$} & \multirow[b]{2}{*}{$\begin{array}{c}\mathrm{R} \\
\text { Square }\end{array}$} & \multirow[b]{2}{*}{$\begin{array}{l}\text { Adjusted } \\
\text { R Square }\end{array}$} & \multirow{2}{*}{$\begin{array}{l}\text { Std. Error } \\
\text { of the } \\
\text { Estimate }\end{array}$} & \multicolumn{5}{|c|}{ Change Statistics } \\
\hline & & & & & $\begin{array}{l}\text { R Square } \\
\text { Change }\end{array}$ & $\begin{array}{c}\mathrm{F} \\
\text { Change }\end{array}$ & df1 & $\mathrm{df} 2$ & $\begin{array}{c}\text { Sig. F } \\
\text { Change }\end{array}$ \\
\hline 1 & $.756^{\mathrm{a}}$ & .572 & .560 & 2.41470 & .572 & 44.823 & 2 & 67 & .000 \\
\hline
\end{tabular}

Dalam Tabel 4 tampak bahwa koefisien korelasi motivasi belajar dan kompetensi pedagogik secara bersamasama terhadap hasil belajar Sosiologi siswa sebesar $\mathrm{R}=+0,756$ dengan signifikansi lebih kecil dari 0,05. Nilai koefisien korelasi ini lebih tinggi bila dihitung berdasarkan kontribusi masingmasing variabel independen. Variabel motivasi dan kompetensi pedagogik guru secara bersama-sama dapat menjelaskan sekitar 57,2\% ( $R$ Square $=0,572)$ hasil belajar Sosiologi siswa. Sementara itu, sebesar $42,8 \%$ hasil belajar Sosiologi siswa dijelaskan oleh factor lain yang tidak diteliti. Korelasi yang positif antara variabel motivasi belajar dan kompetensi pedagogik guru terhadap hasil belajar Sosiologi siswa menunjukan bahwa peningkatan motivasi belajar dan kompetensi pedagogik guru akan membawa perubahan yang positif terhadap hasil belajar Sosiologi siswa. Bila hubungan tersebut digambarkan dalam persamaan regresi linear diperoleh persamaan sebagai berikut: $\widehat{Y}=14.190+$ $0,216 X_{1}+0,126 X_{2}$

\section{Tabel 5}

Koefisien Regresi Motivasi Belajar dan Kompetensi Pedagogik Guru

Terhadap Hasil Belajar Sosiologi Siswa

\begin{tabular}{|c|c|c|c|c|c|c|}
\hline \multirow{2}{*}{\multicolumn{2}{|c|}{ Model }} & \multicolumn{2}{|c|}{$\begin{array}{c}\text { Unstandardized } \\
\text { Coefficients }\end{array}$} & \multirow{2}{*}{$\begin{array}{c}\text { Standardized } \\
\text { Coefficients }\end{array}$} & \multirow[b]{2}{*}{$\mathrm{t}$} & \multirow[b]{2}{*}{ Sig. } \\
\hline & & B & Std. Error & & & \\
\hline \multirow[t]{3}{*}{1} & (Constant) & 14.190 & 2.036 & & 6.971 & .000 \\
\hline & MOTIVASI & .216 & .048 & .414 & 4.496 & .000 \\
\hline & K_PEDAGOGIK & .126 & .025 & .459 & 4.980 & .000 \\
\hline \multicolumn{4}{|c|}{ a. Dependent Variable: HASIL_BELAJAR } & & & \\
\hline
\end{tabular}


Persamaan regresi $\widehat{Y}=14.190+$ $0,216 X_{1}+0,126 X_{2}$ dapat digunakan untuk memprediksi hasil belajar Sosiologi siswa berdasarkan tingkat motivasi belajar siswa dan kompetensi pedagogik guru. Tiap perubahan 1 unit pada variabel motivasi akan berdampak positif pada peningkatan hasil belajar Sosiologi siswa sebesar 0,216. Demikianpun dengan perubahan 1 unit pada kompetensi pedagogik guru akan berdampak positif terhadap hasil belajar Sosiologi sebesar 0,126. Besarnya persentase hasil belajar Sosiologi siswa yang dapat dijelaskan oleh variabel motivasi dan kompetensi pedagogik guru menuntut usaha siswa untuk meningkatkan motivasi belajar dan mendorong guru untuk meningkatkan kompetensi pedagogik.

\section{SIMPULAN}

Prestasi belajar Sosiologi siswa sebagian besar dapat dijelaskan oleh faktor motivasi belajar siswa dan kompetensi pedagogik guru, yaitu sebesar 57,2\%. Besarnya kontribusi variabel motivasi dan kompetensi pedagogik ini menarik perhatian lebih dari para siswa, guru dan stakeholder kependidikan di Kecamatan Langke Rembong. Banyak cara yang dapat ditempuh untuk menumbuhkan motivasi belajar siswa dan meningkatkan kompetensi pedagogik guru. Sekolah hendaknya mengembangkan instrumen dan melakukan pengukuran secara berkala terhadap motivasi belajar siswa. Informasi tentang tinggi rendahnya motivasi siswa dapat membantu pihak sekolah untuk menentukan tindakan yang tepat dalam meningkatkan motivasi belajar siswa. Guru, kepala sekolah, lembaga-lembaga pendidikan juga perlu bersinergi dalam usaha menumbuhkan dan meningkatkan motivasi belajar siswa secara berkesinambungan. Di pihak lain, kompetensi pedagogik juga perlu mendapat perhatian baik oleh guru sendiri maupun oleh pihak sekolah. Pengembangan ilmu dan kemampuan mengelola pembelajaran sudah semestinya diusahakan oleh setiap guru. Tidak sekadar menunggu pelatihanpelatihan yang diselenggarakan pemerintah maupun unit-unit kegiatan guru matapelajaran, pengembangan kemampuan pedagogik juga dapat dilakukan guru secara pribadi melalui kegiatan membaca.

\section{DAFTAR PUSTAKA}

Kirkpatrik Thomas O dan Lewis Chad T. 1995. Effective Supervision Preparing for $21^{\text {st }}$ Century. Orlando: the Dryden Press.

Olivia Femi. Tools for Study Skills: Teknik Ujian Efektif. Jakarta: Elex Media Komputindo. 2011. 
Peraturan Pemerintah Republik Indonesia Nomor 19 Tahun 2005 tentang Standar Nasional Pendidikan.

Sadulloh Uyoh. 2010. Pedagogik Ilmu Mendidik. Bandung: Alfabeta.

Sukidi. 2004. Kecerdasan Spiritual: Mengapa $S Q$ Lebih Penting daripada IQ dan EQ. Jakarta: Gramedia Pustaka Utama.

Suryabrata Sumadi. 1995. Psikologi Pendidikan. Jakarta: Rajawali Pers.

The World Bank, Improving Educational Quality through Enhancing Community Participation: Results from a Randomized Field Experiment in Indonesia, September 2011.
Tim Pengembang FIP-UPI. 2007. Ilmu dan Aplikasi Pendidikan: Ilmu Pendidikan Praktis, Bagian 2. Bandung: PT Imtima.

UNESCO. 2000. Education for All, Status and Trends 2000: Assesing Learning Achievement. Paris: EFA Forum Secretariat.

Yulaelawati Ella. 2009. A New Theory of Education Reform in Indonesia: Globalisation and Recontentextualisation in the Postcolonial Condition. Jakarta: Nagara. 